\title{
A 5 year record of surface energy and mass balance from the ablation zone of Storbreen, Norway
}

\author{
Liss M. ANDREASSEN, ${ }^{1,2}$ Michiel R. VAN DEN BROEKE, ${ }^{3}$ Rianne H. GIESEN, ${ }^{3}$ \\ Johannes OERLEMANS ${ }^{3}$
}

\author{
${ }^{1}$ Section for Glaciers, Snow and Ice, Norwegian Water Resources and Energy Directorate (NVE), \\ PO Box 5091 Majorstua, NO-0301 Oslo, Norway \\ E-mail: Ima@nve.no \\ ${ }^{2}$ Department of Geosciences, University of Oslo, PO Box 1047, Blindern, NO-0316 Oslo, Norway \\ ${ }^{3}$ Institute of Marine and Atmospheric Research, Utrecht University, Princetonplein 5, 3584 CC Utrecht, The Netherlands
}

\begin{abstract}
A 5 year record of data from an automatic weather station (AWS) operating in the ablation zone of Storbreen, Norway, has been used to calculate the local surface energy and mass balance. The AWS observations cover five mass-balance years with an unusually strong mass deficit on Storbreen. The average energy flux $(Q)$ contributing to melt for the period $2001-06$ is $113 \mathrm{~W} \mathrm{~m}^{-2}$. Of this, the net shortwave radiation flux is the dominant contributor $\left(92 \mathrm{~W} \mathrm{~m}^{-2}\right)$, followed by the sensible heat flux $\left(20 \mathrm{~W} \mathrm{~m}^{-2}\right)$ and the latent heat flux $\left(9 \mathrm{~W} \mathrm{~m}^{-2}\right)$. The net longwave radiation $\left(-6 \mathrm{~W} \mathrm{~m}^{-2}\right)$ and the subsurface heat flux $\left(-2 \mathrm{~W} \mathrm{~m}^{-2}\right)$ contribute negatively to the budget. Net radiation thus produces $76 \%$ of the melt, while the turbulent fluxes and the subsurface heat flux produce $24 \%$ of the total melt. The seasonal mean incoming shortwave radiation is remarkably constant between the years, whereas variations in temperature and reflected shortwave radiation (albedo) explain most of the interannual variation in melt. The modelled ablation compares well with the measured ablation from stake readings. The sensitivity of the energy-balance model was examined by varying the surface roughness length of momentum and the sensitivity of the calculated melt by perturbations of temperature, wind speed and relative humidity.
\end{abstract}

\section{INTRODUCTION}

The relation between meteorological quantities and the mass balance of a glacier surface is important for understanding physical processes governing melt and for modelling the reaction of glaciers to climate change. Melt at the glacier surface is controlled by the surface energy balance (SEB), which can be expressed as:

$$
S_{\text {in }}+S_{\text {out }}+L_{\text {in }}+L_{\text {out }}+H_{\mathrm{S}}+H_{\mathrm{L}}+G-Q=0,
$$

where $S_{\text {in }}$ is incoming shortwave (solar) radiative flux, $S_{\text {out }}$ is outgoing/reflected shortwave radiative flux, $L_{\text {in }}$ is incoming longwave radiative flux, $L_{\text {out }}$ is outgoing longwave radiative flux, $H_{\mathrm{S}}$ is sensible heat flux, $H_{\mathrm{L}}$ is latent heat flux, $G$ is the subsurface heat flux and $Q$ is melting energy. Fluxes are defined as positive when directed towards the surface. Thus the melting energy, $Q$, can be expressed as:

$$
Q=S_{\text {net }}+L_{\text {net }}+H_{\mathrm{S}}+H_{\mathrm{L}}+G,
$$

where $S_{\text {net }}$ is the sum of the shortwave components, $S_{\text {in }}+S_{\text {out }}$, and $L_{\text {net }}$ is the sum of the longwave components, $L_{\text {in }}+L_{\text {out }}$.

Previous measurements have shown that over melting glaciers $S_{\text {net }}$ is the most important contributor (e.g. Greuell and Genthon, 2004), and that the radiative fluxes $\left(S_{\text {net }}+L_{\text {net }}\right)$ often account for $50-80 \%$ of the melt energy, while the turbulent fluxes $\left(H_{\mathrm{S}}+H_{\mathrm{L}}\right)$ contribute $20-50 \%$ of the melt (Willis and others, 2002; Hock, 2005). Furthermore, previous studies have shown that the radiative fluxes are most important at continental alpine glaciers, while turbulent fluxes are more important for glaciers in more maritime conditions (Willis and others, 2002). In order to study the importance of different components of the SEB on glacier melt in Norway, energy-balance studies were carried out on ten glaciers for the period 1955-81 (Liestøl, 1967; Klemsdal, 1970; Messel, 1971, 1985). A summary of these studies revealed that the relative importance of $S_{\text {net }}$ was largest in the drier interior and decreased towards the west coast (Messel, 1985). Most of the previous studies of the surface energy balance on melting glaciers have been undertaken over shorter periods, from a few weeks to a few months. As the relative importance of the different components of the SEB depends strongly on weather conditions, their relative contributions may change during the melt season and from year to year (Hock, 2005). Although $S_{\text {net }}$ usually is the dominant contributor over melting glaciers, it is the turbulent fluxes and $L_{\text {net }}$ that are directly affected by temperature changes, and it is therefore important to model them correctly when studying the climate sensitivity of glaciers. Use of automatic weather stations (AWS) provides the opportunity to obtain long and continuous records of meteorological data and to study the seasonal and interannual variations in the SEB at point locations (e.g. Oerlemans, 2000; Reijmer and Oerlemans, 2002; Mölg and Hardy, 2004) and to calibrate spatially distributed energy- and mass-balance models that use input data from stations outside the glacier (e.g. Arnold and others, 1996; Klok and Oerlemans, 2002).

Since September 2001 an AWS has operated in the ablation zone of Storbreen, Norway, providing a unique and near-continuous record of meteorology and mass balance of a glacier in the transition zone between maritime and continental glaciers. The AWS record from Storbreen is particularly interesting, since the glacier has one of the longest mass-balance series in the world, with a continuous 


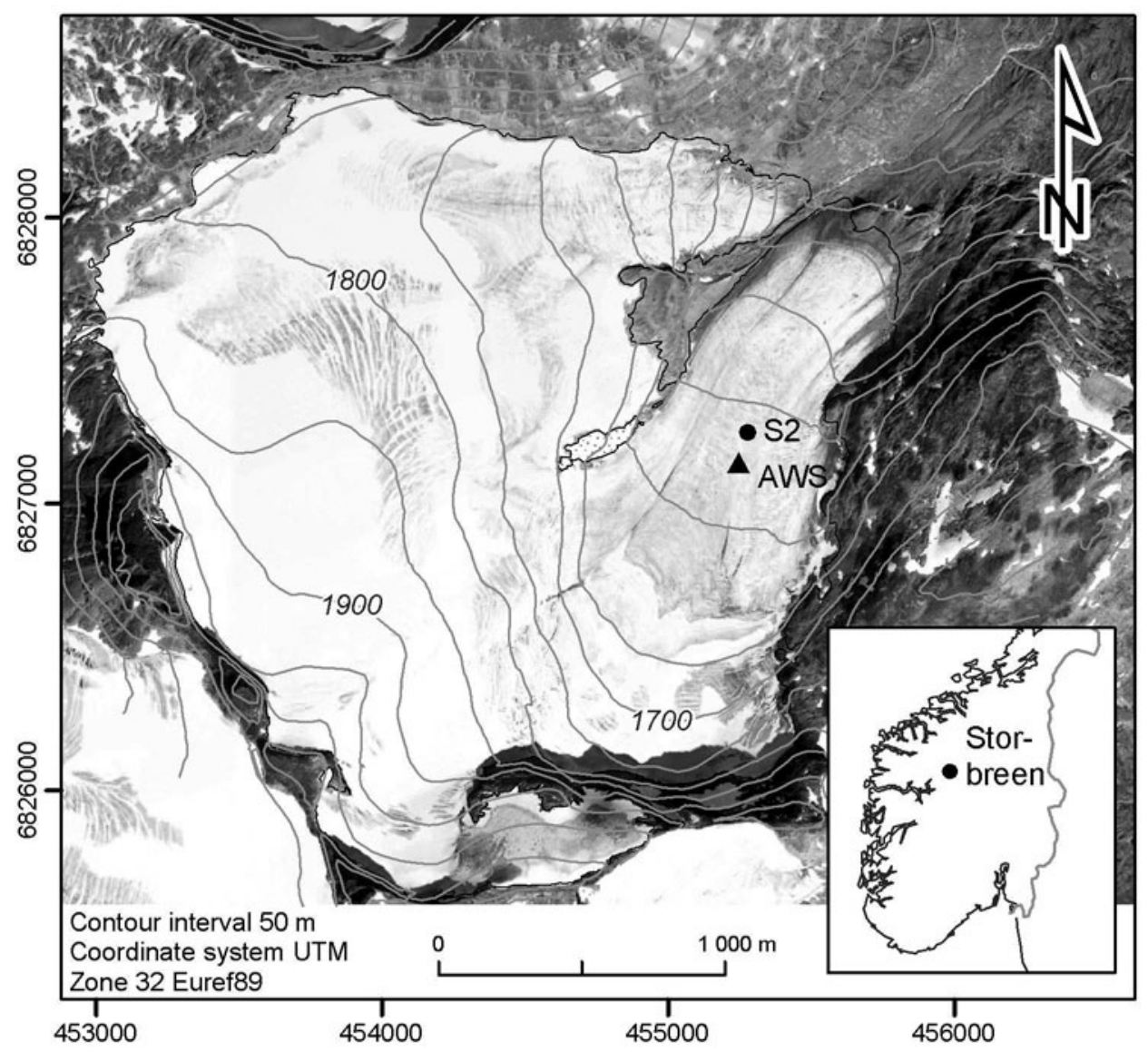

Fig. 1. Location map of Storbreen in southern Norway showing the position of the AWS and stake 2 (S2). Glacier contours and outline from 1997 are draped on an orthophoto from August 2004. The image is delivered by norgeibilder.no.

record since 1949 . The long record of Storbreen has been used for assessments and modelling in several studies (e.g. Dyurgerov, 2000; Ohmura, 2006; Rasmussen and others, 2007). In this paper, we report on the mass balance and the surface energy balance and its components calculated from the AWS data of Storbreen for the five mass-balance years from 2001/02 to 2005/06. We use a physically based energy-balance model previously applied to AWS data from Antarctica (e.g. Van den Broeke and others, 2005) to determine the SEB. The model calculates the turbulent fluxes, $L_{\text {out }}$ and the subsurface heat flux as functions of the surface temperature, while the other fluxes are measured directly at the AWS. We study the interannual variations and also compare our data with results obtained at the glacier in the summer of 1955 (Liestøl, 1967). We also investigate the sensitivity of the surface energy balance by perturbations of the input data, and the sensitivity of the model by varying the surface roughness length of momentum.

\section{SETTING}

Storbreen $\left(61^{\circ} 36^{\prime} \mathrm{N}, 8^{\circ} 8^{\prime} \mathrm{E}\right)$ is located in the western part of Jotunheimen, the highest elevated mountain massif in Norway (Fig. 1). The glacier has a total area of $5.4 \mathrm{~km}^{2}$ and ranges in altitude from 1390 to $2090 \mathrm{ma.s.l}$. The mean equilibrium-line altitude is $1763 \mathrm{~m}$ a.s.l. (Andreassen and others, 2005). The length of this east-facing glacier is $3 \mathrm{~km}$, and it has an average slope of $14^{\circ}$ (Andreassen, 1999). Storbreen has well-defined borders, and may be characterized as a short valley glacier or a composite cirque glacier. A subglacial ridge divides the glacier into two well-defined parts. Mass-balance investigations have been carried out every year since measurements began in 1949. The glacier is part of an east-west mass-balance transect in southern Norway where mass turnover is largest near the west coast and decreases towards the drier interior. Storbreen is in this respect considered as a continental glacier, with a smaller mass-balance turnover than the glaciers situated farther west and with a higher dependence on the summer balance than winter balance for the interannual variability in the net balance (e.g. Nesje and others, 2000; Andreassen and others, 2005; Rasmussen and Andreassen, 2005).

Micro-meteorological observations were carried out on Storbreen in the summer of 1955 (Liestøl, 1967). A meteorological station was erected at $1600 \mathrm{~m}$ a.s.l., measuring shortwave radiation, wind speed, relative humidity, air temperature and surface height. The data were used to calculate daily values of the SEB. The calculations revealed that net radiation contributed $56 \%$, convection $\left(H_{\mathrm{S}}\right) 31 \%$ and condensation $\left(H_{\mathrm{L}}\right) 13 \%$ to the melt at this location. Extrapolation to the whole glacier for a 10 day period gave almost the same results.

\section{METHODS}

\section{Mass-balance observations}

The mass balance at the AWS site is measured using standard methods (Østrem and Brugman, 1991) as part of 
the mass-balance programme on the glacier (e.g. Kjøllmoen and others, 2007). The accumulated winter snow is measured in May by probing to the previous summer surface. Snow density is measured in one pit at the AWS. Ablation stakes are used to measure the relative elevation of the surface at the AWS and keep track of the accumulation and melting. We use between one and four stakes at the AWS. In addition we use readings from stake 2 of the ordinary stake network of Storbreen, situated $90 \mathrm{~m}$ north of the AWS (Fig. 1). The summer ablation is measured by stake readings in September. Supplementary stake readings are carried out in July/August and often also in March/April. The winter $\left(b_{w}\right)$ and summer balance $\left(b_{\mathrm{s}}\right)$ are calculated separately and the resulting net balance $\left(b_{\mathrm{n}}\right)$ is calculated as the sum of the two components,

$$
b_{\mathrm{n}}=b_{\mathrm{w}}+b_{\mathrm{s}}
$$

The mass balance at Storbreen is calculated using the stratigraphic method, i.e. between two successive 'summer surfaces' (surface minima). Melting after the ablation measurements may occur in warm periods late in autumn, especially at the lower elevations of the glacier where the AWS is located. Melting after the last ablation measurement is considered part of the following year's winter balance. Thus, the reported winter balance, $b_{\mathrm{w}}$, may in some years be smaller than the reported winter accumulation, $b_{\mathrm{acc}}$. This was the case in the mass-balance year 2001/02 when additional melting occurred after the ablation measurement on 26 September. The reported $b_{\mathrm{w}}$ for the glacier total was $1.1 \mathrm{~m}$ w.e., while $b_{\text {acc }}$ was $1.2 \mathrm{~m}$ w.e. For the other massbalance years in the period of AWS observations the reported $b_{\mathrm{w}}$ was not adjusted for any additional melt.

\section{AWS description}

The AWS is located in the ablation zone of Storbreen, at $\sim 1570$ ma.s.l. on a relatively flat and homogeneous ice surface with a mean surface slope of $6^{\circ}$ (Fig. 1). The station was erected on 6 September 2001, and in this paper we analyze the data for the period 6 September 2001 to 10 September 2006. The station is part of the Institute of Marine and Atmospheric research Utrecht (IMAU) network of AWS on glaciers (http://www.phys.uu.nl/ wwwimau/ research/ice_climate/aws/). The AWS stands freely on the ice and sinks with the melting surface. Data are sampled every few minutes and then converted into 30 min mean values and stored in a data logger. The mast has two arms carrying instruments, one at $\sim 5.7 \mathrm{~m}$ and one at $\sim 2.4 \mathrm{~m}$ above the ice surface (Fig. 2). At both levels air temperature $(T)$, relative humidity $(\mathrm{RH})$, wind speed (WS)

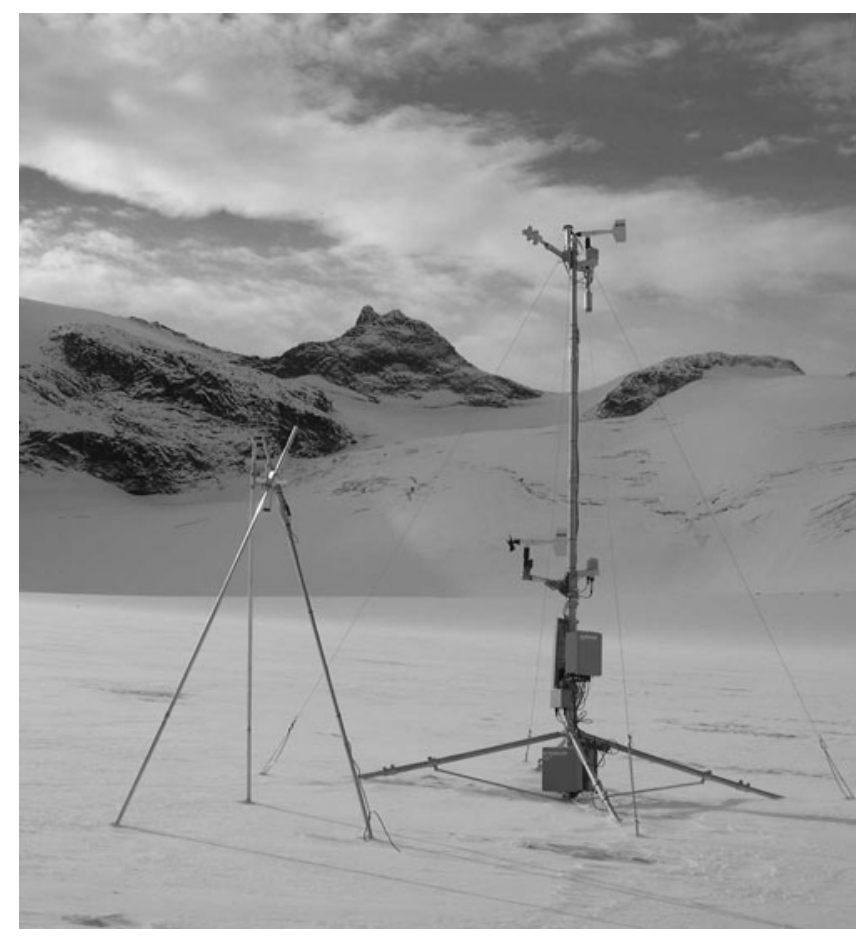

Fig. 2. The AWS at Storbreen. Measurements of relative humidity, temperature and wind are made at two levels above the ice surface. The tripod to the left measures surface height.

and wind direction are measured. At the upper arm the four components of the radiation budget $\left(S_{\text {in }}, S_{\text {out }}, L_{\text {in }}\right.$ and $\left.L_{\text {out }}\right)$ and surface height are measured. Air pressure is measured in the electronics enclosure. In addition, surface height is measured with a sonic ranger at a tripod drilled into the ice (Fig. 2). Specifications of the AWS instruments used to calculate the SEB are listed in Table 1.

\section{AWS data treatment}

The net shortwave radiation was calculated using the accumulated albedo, $\alpha_{\mathrm{acc}}$, defined as the ratio of the running mean $S_{\text {out }}$ and the running mean $S_{\text {in }}$ over a time window of 24 hours (Van den Broeke and others, 2004). The albedo, $\alpha_{\text {acc }}$ is then used together with instantaneous $S_{\text {out }}$ to calculate $S_{\text {net }}$. This method improves $S_{\text {net, }}$ but removes the daily cycle in albedo. This is preferred because the daily cycle in albedo is strongly affected by the tilt of the radiation instrument and the poor cosine response of the radiation sensor at low sun angles. The relative humidity data were corrected with respect to ice instead of water when

Table 1. Overview of the AWS instruments and their specifications that were used to calculate the SEB

\begin{tabular}{llll}
\hline & Type & Range & Accuracy \\
& & & \\
Shortwave radiation & Kipp CNR1 & $0-2000 \mathrm{~W} \mathrm{~m}^{-2}$ & $\pm 10 \%$ for daily sums \\
Longwave radiation & Kipp CNR1 & -250 to $+250 \mathrm{~W} \mathrm{~m}^{-2}$ & $\pm 10 \%$ for daily sums \\
Air temperature & Vaisala HMP45C & -39.2 to $+60^{\circ} \mathrm{C}$ & $\pm 0.2\left(\right.$ at $\left.+20^{\circ} \mathrm{C}\right)$ \\
& & & $\pm 0.5\left(\right.$ at $\left.-39.2{ }^{\circ} \mathrm{C}\right)$ \\
Relative humidity & Vaisala HMP45C & $0.8-100 \%$ & $\pm 2-3 \%$ \\
Wind speed & Young 05103 & $1-100 \mathrm{~m} \mathrm{~s}^{-1}$ & $\pm 0.3 \mathrm{~m} \mathrm{~s}^{-1}$ \\
Surface height & Campbell SR50 & $0.5-10 \mathrm{~m}$ & $\pm 0.01 \mathrm{~m}$
\end{tabular}

Note: The specifications are given by the manufacturers. The accuracy of the surface height measurements might be lower due to tilt and snow creep. 


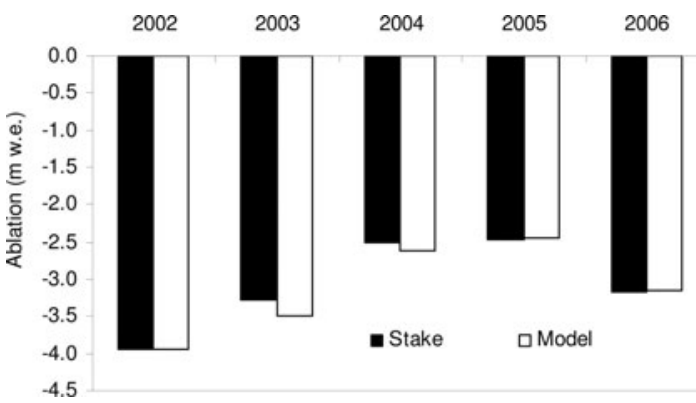

Fig. 3. Measured summer ablation from stakes and the calculated ablation (as runoff) from the SEB model. The period of measured and calculated ablation is between the observation dates in May and September (see Table 4).

temperatures were $<0^{\circ} \mathrm{C}$ using the expression of Curry and Webster (1999). In order to avoid errors in the temperature due to overheating of the sensor, a problem well known for unaspirated sensors in relation to high $S_{\text {net }}$ and low wind speed, the temperature data were corrected using a routine developed by Smeets (2006). This routine uses wind speed and the sum of $S_{\text {in }}$ and $S_{\text {out }}$ as input and was developed based on Greenland measurements.

The AWS provides a near-continuous record of meteorological observations from 6 September 2001 to 10 September 2006. Data are missing for the lower level for parts of three of the five winter seasons when accumulated snow buried the lower arm and damaged the wind sensor at this level. The tripod with sonic ranger was buried by snow in several winters and melted out of the ice in some summers. Thus, for some periods the surface elevation data are not continuous and readings of the ablation stakes are used to keep track of the cumulative melt in periods with missing data. The AWS fell down on 30 July 2004 (due to the opening of a crevasse) and rested horizontally on the surface until it was re-erected on 17 August 2004. Although the sensors measured continuously in this period, their orientation and height above the surface had changed and most of the data could not be used. The only variable we kept unchanged was air pressure as it is not so sensitive to the measurement height and also has a minor influence on the SEB compared to the other variables. For the variables $S_{\text {in }}, W S, L_{\text {in }}$ and $T$ we chose to use data from an identical AWS located on Midtdalsbreen, a northeast-facing outlet glacier from the ice cap Hardangerjøkulen located $120 \mathrm{~km}$ southwest of Storbreen; this AWS is also operated by IMAU. A comparison of the two datasets has shown that all the variables measured showed similar and simultaneous fluctuations (Giesen and others, unpublished information). Alternatively, we could have used average values for this period from the other years at Storbreen, but this would have damped the interannual variability which was what we intended to study. Furthermore, using the correlation with Midtdalsbreen preserves the inter-daily variations. We filled the $S_{\text {in }}$ and WS record by multiplying the data from Midtdalsbreen with the ratio of summed values measured on Storbreen and Midtdalsbreen for the period of the data gap in the other years. $L_{\text {in }}$ and $T$ were calculated using the mean difference of the values between the two glaciers for the period considered. We calculated $S_{\text {out }}$ using the average ice albedo for the same period in 2002, 2003 and 2006. We assumed that $L_{\text {out }}$ was constant at $315.6 \mathrm{~W} \mathrm{~m}^{-2}$ (as for a melting surface). Although the data gap is only 19 days and the correlation with Midtdalsbreen is good, the resulting data from the summer of 2004 are more uncertain than the other years and should be interpreted with some care.

\section{Calculation of turbulent fluxes}

The turbulent fluxes were calculated by the bulk method where Monin-Obukhov similarity theory is applied to one atmospheric level and the surface. The bulk method is effective in determining turbulent scaling parameters, even under conditions of shallow katabatic flow (Denby and Greuell, 2000), and is not sensitive to errors in measured profiles because the near-surface gradients by far exceed those higher in the surface layer. We assume that at the glacier surface the wind speed is zero and that the air is saturated. The sensible and latent heat fluxes, $H_{\mathrm{S}}$ and $H_{\mathrm{L}}$, are calculated as:

$$
\begin{aligned}
& H_{\mathrm{S}}=\rho c_{\mathrm{p}} u_{*} \theta_{* \prime} \\
& H_{\mathrm{L}}=\rho L_{\mathrm{V}, \mathrm{s}} u_{*} q_{* \prime}
\end{aligned}
$$

where $\rho$ is air density, $C_{\mathrm{p}}$ is the specific heat capacity of dry air at constant pressure $\left(c_{\mathrm{p}}=1005 \mathrm{~J} \mathrm{~K}^{-1} \mathrm{~kg}^{-1}\right)$, and $L_{\mathrm{v}, \mathrm{s}}$ is the latent heat of vaporization or sublimation depending on the surface temperature. The turbulent scales of wind speed, temperature and humidity $\left(u_{*}, \theta_{*}\right.$ and $q_{*}$, respectively) can be approximated as:

$$
\begin{aligned}
& u_{*}=\frac{\kappa\left[v\left(z_{\mathrm{v}}\right)-v\left(z_{0 \mathrm{v}}\right)\right]}{\ln \left(\frac{z_{\mathrm{v}}}{z_{0 \mathrm{v}}}\right)-\psi_{\mathrm{m}}\left(\frac{z_{\mathrm{v}}}{L}\right)}, \\
& \theta_{*}=\frac{\kappa\left[\theta\left(z_{\mathrm{T}}\right)-\theta\left(z_{0 \mathrm{~T}}\right)\right]}{\ln \left(\frac{z_{\mathrm{T}}}{z_{0 \mathrm{~T}}}\right)-\psi_{\mathrm{h}}\left(\frac{z_{\mathrm{T}}}{L}\right)}, \\
& q_{*}=\frac{\kappa\left[q\left(z_{\mathrm{q}}\right)-q\left(z_{0 \mathrm{q}}\right)\right]}{\ln \left(\frac{z_{\mathrm{q}}}{z_{0 \mathrm{q}}}\right)-\psi_{\mathrm{h}}\left(\frac{z_{\mathrm{q}}}{L}\right)},
\end{aligned}
$$

where $\kappa=0.4$ is the von Kármán constant, $z_{\mathrm{v}}, z_{\mathrm{T}}$ and $z_{\mathrm{q}}$ are the measurement levels of wind speed, temperature and humidity, $z_{\mathrm{Ov}}, z_{\mathrm{OT}}$ and $z_{\mathrm{Oq}}$ are the surface roughness lengths associated with $v, T$ and $q$ (momentum, heat and moisture), and $\psi_{\mathrm{m}}$ and $\psi_{\mathrm{h}}$ are the vertically integrated stability corrections for momentum and heat, respectively. The Obukhov length scale, $L$, is defined as:

$$
L=\frac{u_{*}^{2}}{\frac{\kappa g}{\theta}\left(\theta_{*}+0.62 \theta q_{*}\right)},
$$

where $g$ is the gravitational acceleration. The wind-speed, relative-humidity and air-temperature data from the upper arm were used as atmospheric input data. Preferably the wind-speed data from the lower arm should be used since at sloping glaciers shallow katabatic winds can occur quite often at $\sim 2 \mathrm{~m}$ height (e.g. Denby and Greuell, 2000) and the upper arm could miss the strong near-surface shear that results. We used the stability functions proposed by Holtslag and de Bruin (1988), which yield the most physically realistic corrections under stable conditions (Andreas, 2002), occurring $>95 \%$ of the time on Storbreen. The stability functions by Dyer (1974) were used for unstable conditions. When using the wind speed from the upper measurement level, the stability correction will have a tendency to reduce the estimate of the turbulent fluxes. Therefore, based on comparison with the lower level, we limited the flux reduction under stable conditions to be one-third.

To calculate the roughness length of momentum, $z_{0 v}$, we compared the wind speed measured at the lower and upper 
arm under near-neutral conditions, i.e. at high wind speeds. Due to the rather low wind speeds at Storbreen, very few data points were available and they were biased towards winter. A comparison of the $z_{0 v}$ values derived for Storbreen and Midtdalsbreen showed that the values were similar in periods when they were available for both stations. Therefore, we decided to use the calculated median $z_{0 v}$ values derived for snow $(0.13 \mathrm{~mm})$ and ice $(0.75 \mathrm{~mm})$ surfaces at the AWS location on Midtdalsbreen. The model thus uses a two-step $z_{0 v}$ value, $0.13 \mathrm{~mm}$ when the surface is snow and $0.75 \mathrm{~mm}$ when the surface is ice. Roughness lengths for heat $\left(z_{\mathrm{OT}}\right)$ and moisture $\left(z_{\mathrm{Oq}}\right)$ were calculated within the model using the expressions of Andreas (1987).

\section{Calculation of the melting energy $(Q)$ and melt $(M)$}

The energy available for melt, $Q$, at the AWS location of Storbreen was calculated using Equation (2). The energy fluxes are defined as positive when directed towards the surface. The model treats the surface as a 'skin' layer without heat capacity, and the heat added or removed by precipitation is neglected. The time-step is $10 \mathrm{~min}$ and model input is obtained by linear interpolation from the $30 \mathrm{~min}$ values from the AWS. The $S_{\text {in }}, S_{\text {out }}$ and $L_{\text {in }}$ are taken directly from observed and corrected data, while $L_{\text {out }}, H_{\mathrm{S}}, H_{\mathrm{L}}$ and $G$ are written as functions of the surface temperature $T_{\mathrm{s}} . H_{\mathrm{S}}$ and $H_{\mathrm{L}}$ are calculated from the wind speed, relative humidity and temperature data using Equations (4-9). The subsurface heat flux, $G$, is calculated using the snow/ice temperature gradient just below the surface. The model uses an iterative procedure to solve the SEB for $T_{\mathrm{s}}$. The full solving procedure is described in Van den Broeke and others (2005). When the $T_{\mathrm{s}}$ found by the model exceeds the melting point, $T_{\mathrm{s}}$ is set back to $0^{\circ} \mathrm{C}$ and the excess energy is used for melting. The surface melt, $M$, is calculated as:

$$
M=\frac{Q}{L_{f}},
$$

where $L_{\mathrm{f}}$ is the latent heat of fusion $\left(L_{\mathrm{f}}=3.34 \times 10^{5} \mathrm{~J} \mathrm{~kg}^{-1}\right)$. Meltwater is routed through the snowpack as described below.

\section{Subsurface model}

A subsurface model was used to calculate snow and ice temperatures and liquid water content in the snowpack, and to allow for refreezing. Heat conduction in the snow is calculated by solving the one-dimensional heat-transfer equation on grid levels spaced $0.04 \mathrm{~m}$ apart down to $20 \mathrm{~m}$ depth. The initial temperature profile is obtained by running the model for a year (summer 2001 to summer 2002), and the resulting subsurface temperature profile is used for model initialization. The temperature at $20 \mathrm{~m}$ depth is supposed to remain stable. Once $T_{\mathrm{s}}$ reaches the melting point, the available energy calculated from Equation (2) is redirected to melting. Meltwater is allowed to penetrate into the snowpack and refreeze. If the meltwater reaches the ice surface without refreezing, it is assumed to run off. The number of snow layers is dictated by the observed/ reconstructed snow depth. A constant snow density of $500 \mathrm{~kg} \mathrm{~m}^{-3}$ is used.

\section{Validation of the calculated SEB}

In our model, $T_{\mathrm{s}}$ is calculated by the model by solving Equation (1) for $T_{\mathrm{s}}$ and thus closing the energy balance. In

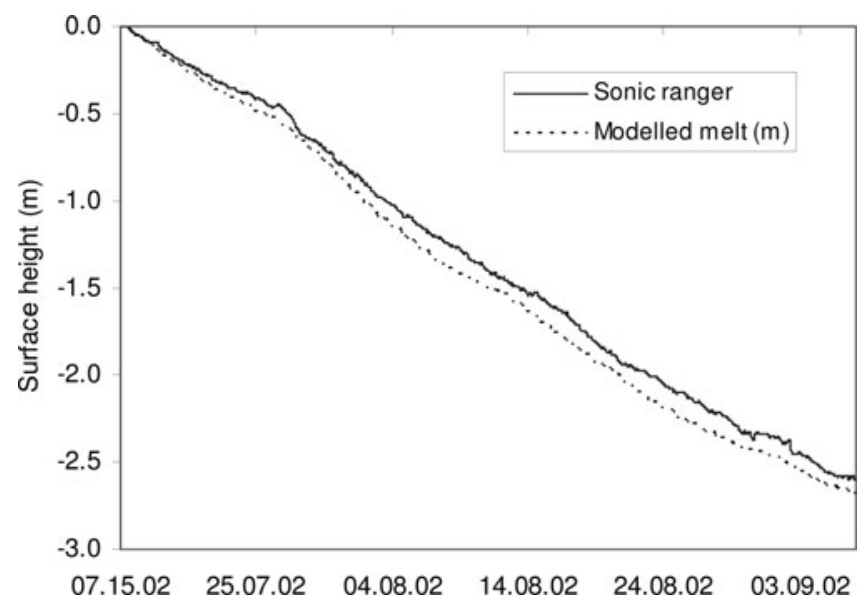

Fig. 4. Surface lowering during ice melt measured from sonic ranger and calculated from the model in 2002. Modelled runoff is converted from $\mathrm{m}$ w.e. to $\mathrm{m}$ assuming an ice density of $900 \mathrm{~kg} \mathrm{~m}^{-3}$.

order to validate the robustness of the SEB calculations, we also calculated the SEB using the observed $T_{\mathrm{s}}$ (calculated from observed $L_{\text {out }}$ assuming unit emissivity of the surface). In this method, the surface energy balance does not necessarily close because of errors in the measurements and model calculations. A problem for calculating $T_{\mathrm{s}}$ using this method is that $\mathrm{L}_{\text {out }}$ received at the sensor will include radiation emitted by the atmosphere between the glacier surface and the sensor, particularly when the air is much warmer than the surface. This problem is potentially serious under melting conditions. However, as we maximize observed $T_{\mathrm{S}}$ at the melting point when comparing observed and modelled $T_{\mathrm{s}}$, this will not have a large effect on the results. The average difference in $T_{\mathrm{s}}$ between the two methods is $0.08^{\circ} \mathrm{C}$ with a root-mean square error (rmse) of $1.3^{\circ} \mathrm{C}$, which is a good result given the uncertainties in the data and SEB calculation methods. The total melt calculated using the observed $T_{\mathrm{S}}$ and modelled $T_{\mathrm{S}}$ was 17.38 and $17.65 \mathrm{~m}$ w.e., respectively. The difference in melt is $0.27 \mathrm{~m}$ w.e., or $0.05 \mathrm{~m}$ w.e. $\mathrm{a}^{-1}$, and is small compared to the total melt. In the following we refer to the results calculated from the model using the modelled $T_{\mathrm{s}}$.

We also compared the runoff (i.e. melt - refreezing) calculated from the SEB with the measured surface lowering from stakes between the observation dates in May and September (Fig. 3). The results generally agree well. The rmse of the modelled melt from the AWS data and the observed melt from the stakes is $0.11 \mathrm{~m}$ w.e., which is within the uncertainty of the stake readings and SEB calculations. Note that the ablation calculated from stakes is based on the surface lowering, so that possible melt of new snow after the accumulation season will not be included, whereas the model calculates total melt from the SEB. Thus, summer snowfalls may explain some of the difference. The amount of ablation from summer snow is small at the altitude of the AWS, however, and not considered important. A comparison of the cumulative melt with melt calculated from the sonic-ranger data when the surface is ice showed very good agreement where data were available (Fig. 4). It is not possible to make this comparison for the snowmelt period, as the snow density will vary and the variation in snow density is not measured. 

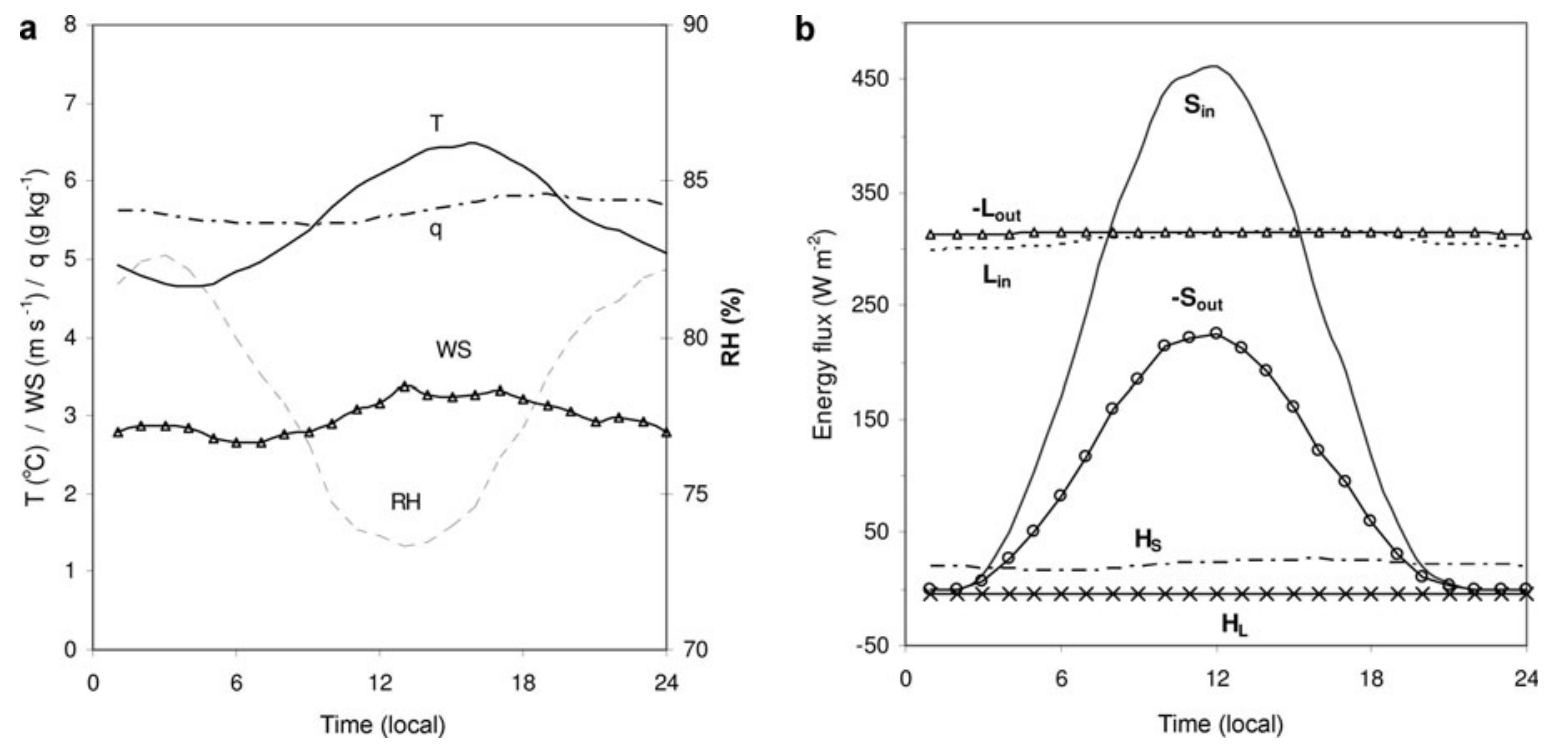

Fig. 5. Mean daily cycles during the period 1 May to 1 October 2003 of (a) air temperature $(T)$, wind speed (WS), specific humidity $(q)$ and relative humidity $(\mathrm{RH})$ and $(\mathrm{b})$ the absolute values of radiative and turbulent fluxes.

\section{RESULTS}

\section{Wind speed, air temperature and humidity}

To compare the weather conditions in each summer season we averaged the data over the period 1 June to 10 September which is the dominant melt period, hereafter referred to as the summer mean (Table 2). The summer mean wind speed at Storbreen varies between 3.0 and $3.5 \mathrm{~m} \mathrm{~s}^{-1}$ (Table 2). The wind has a small but noticeable daily cycle, with maximum wind speeds early in the afternoon; the second maximum slightly lags air temperature (Fig. 5). The dominant wind direction is down-glacier. Liestøl (1967) reported a 'pronounced "Gletscherwind"" on Storbreen, especially on days with good weather. The low-level summer wind and the dominant wind direction down the glacier indicate that the wind flow at the AWS is of katabatic origin most of the time, which is typical for many glaciers (Van den Broeke, 1997; Oerlemans and Grisogono, 2002).

The mean summer temperature at the upper level varies within $2^{\circ} \mathrm{C}$. The summer of 2002 was the warmest, with a mean of $6.3^{\circ} \mathrm{C}$, while the summers of 2004 and 2005 were the coldest, with means of 4.5 and $4.4^{\circ} \mathrm{C}$, respectively. The interannual variation of temperature is also illustrated as cumulative sums of daily positive temperatures (Fig. 6), where 2006 was almost as warm as 2002. Figure 6 also reveals a warm period during autumn 2005. The mean daily cycle shows a range in temperature of $\sim 2^{\circ} \mathrm{C}$, with a maximum in early afternoon (Fig. 5).

The summer mean of the relative humidity $(\mathrm{RH})$ is $77.7 \%$, with a minimum value of $75.2 \%$ (2006) and maximum of $79.6 \%$ (2005). The mean specific humidity is $5.5 \mathrm{~g} \mathrm{~kg}^{-1}$ and varies from 5.0 (2004) to $5.9 \mathrm{~g} \mathrm{~kg}^{-1}$ (2002).

Table 2. Mean values of variables calculated from the AWS data from Storbreen for the period 1 June to 10 September. The variables are measured at the upper arm ( $\sim 5.7 \mathrm{~m}$ above the ice surface)

\begin{tabular}{|c|c|c|c|c|c|c|}
\hline Variable & 2002 & 2003 & 2004 & 2005 & 2006 & $2002-06$ \\
\hline Wind speed, WS $\left(\mathrm{m} \mathrm{s}^{-1}\right)$ & 3.1 & 3.0 & 3.0 & 3.5 & 3.2 & 3.2 \\
\hline Relative humidity, RH (\%) & 77.4 & 78.2 & 77.7 & 79.6 & 75.2 & 77.7 \\
\hline Specific humidity, $q\left(\mathrm{~g} \mathrm{~kg}^{-1}\right)$ & 5.9 & 5.6 & 5.0 & 5.3 & 5.6 & 5.5 \\
\hline Temperature, $T\left({ }^{\circ} \mathrm{C}\right)$ & 6.3 & 5.5 & 4.5 & 4.4 & 5.9 & 5.3 \\
\hline Shortwave in, $S_{\text {in }}\left(\mathrm{W} \mathrm{m}^{-2}\right)$ & 183 & 185 & 185 & 185 & 184 & 185 \\
\hline Shortwave out, $S_{\text {out }}\left(\mathrm{W} \mathrm{m}^{-2}\right)$ & -86 & -90 & -100 & -119 & -90 & -97 \\
\hline Longwave in, $L_{\text {in }}\left(\mathrm{W} \mathrm{m}^{-2}\right)$ & 313 & 307 & 302 & 305 & 304 & 306 \\
\hline Longwave out, $L_{\text {out }}\left(\mathrm{W} \mathrm{m}^{-2}\right)$ & -315 & -315 & -314 & -314 & -315 & -315 \\
\hline Sensible, $H_{\mathrm{S}}\left(\mathrm{W} \mathrm{m}^{-2}\right)$ & 24 & 21 & 17 & 20 & 24 & 21 \\
\hline Latent, $H_{\mathrm{L}}\left(\mathrm{W} \mathrm{m}^{-2}\right)$ & 15 & 12 & 5 & 10 & 11 & 11 \\
\hline Subsurface heat flux, $G\left(\mathrm{~W} \mathrm{~m}^{-2}\right)$ & 0 & 1 & 2 & 3 & 1 & 1 \\
\hline Turbulent scale of WS, $u_{*}$ & 0.11 & 0.11 & 0.11 & 0.13 & 0.11 & 0.11 \\
\hline Turbulent scale of $T, \theta_{*}$ & 0.21 & 0.19 & 0.16 & 0.16 & 0.21 & 0.19 \\
\hline Transmissivity, $\tau$ & 0.44 & 0.45 & 0.45 & 0.45 & 0.45 & 0.45 \\
\hline Albedo, $\alpha$ & 0.45 & 0.46 & 0.51 & 0.60 & 0.44 & 0.49 \\
\hline
\end{tabular}




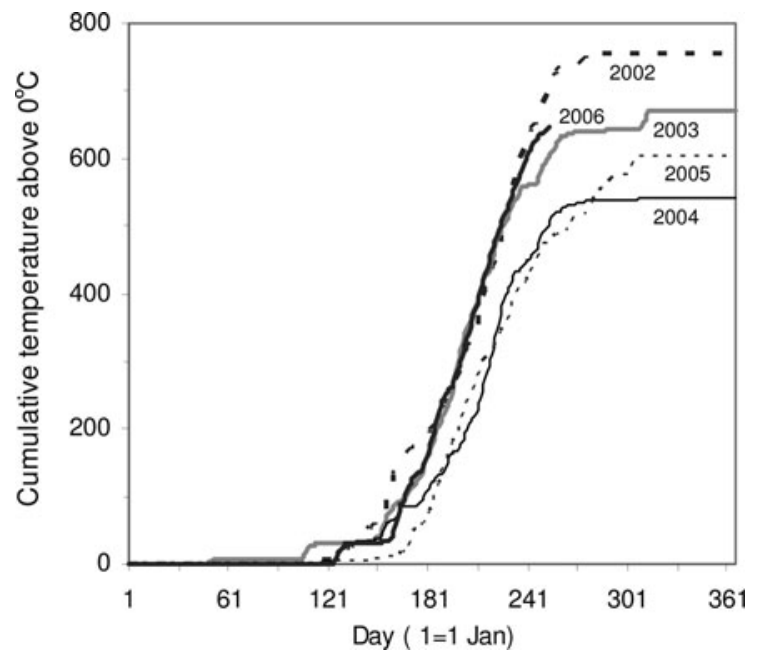

Fig. 6. Cumulative daily air temperature (when daily temperature $>0^{\circ} \mathrm{C}$ ) at the upper level at the AWS on Storbreen for the years 2002 06. In 2006 measurements were available until 10 September.

\section{Shortwave radiation}

Summer mean $S_{\text {in }}$ is remarkably stable in the period 1 June to 10 September and varies between 183 and $185 \mathrm{~W} \mathrm{~m}^{-2}$ over the 5 years (Table 2 ), while $S_{\text {out }}$ varies considerably between the years, between -86 (2002) and $-119 \mathrm{~W} \mathrm{~m}^{-2}$ (2005). Thus, the variation in the contribution to interannual variation in $S_{\text {net }}$ (Table 3 ) is mainly caused by variation in $S_{\text {out, }}$ due to differences in albedo.

The net shortwave radiation observed at Storbreen has a distinct daily cycle in contrast to the smaller daily cycles in the turbulent and longwave fluxes (Fig. 5). The atmospheric transmissivity, $\tau$, is defined as the fraction of the top-ofatmosphere (TOA) radiation reaching the glacier surface. The seasonal mean $\tau$ ranges between 0.44 and 0.45 (Table 2); in other words less than half of the TOA radiation reaches the glacier surface. While the seasonal mean is remarkably constant because there is little variation in $S_{\text {in }}$ in this period, the daily $\tau$ averaged for the 5 year observation period reveals that $\tau$ is highest from mid-March to mid-June and then drops markedly from June to September (Fig. 7). This indicates more clear-sky weather in spring and cloudier conditions in late summer and autumn at Storbreen. Shading

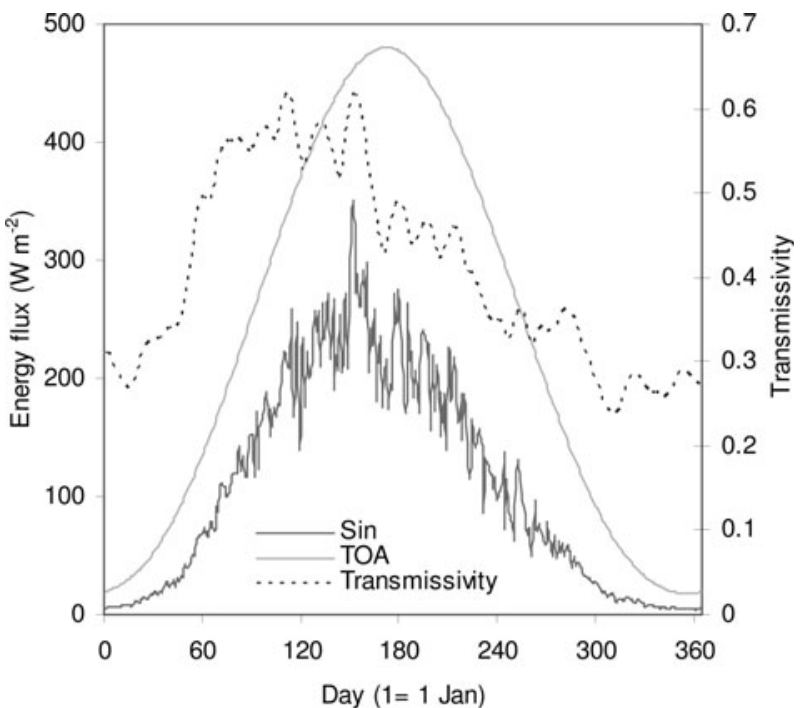

Fig. 7. Daily averages (2001-06) of $S_{\text {in, }}$ atmospheric transmissivity $(\tau)$ and TOA radiation.

can be a significant factor on the shortwave radiation at many glaciers (Oerlemans, 2001), but is not very dominant at the AWS location as revealed from the daily cycle in $S_{\text {in }}$ (Fig. 5). The glacier is relatively wide and the mountain walls surrounding parts of the glacier are not too steep and do not range very high above the glacier. Thus, the main reduction in $S_{\text {in }}$ compared to the TOA radiation is due to atmospheric conditions and not shading.

\section{Albedo}

Figure 8 illustrates the development in daily surface albedo in 2003 and 2005, two rather different years with respect to snow accumulation and melting. In both years, the dry snow albedo fluctuates around 0.9. In 2003 several early melt episodes lowered the snow albedo significantly. The 2003 winter accumulation at the AWS was $20 \%$ below the mean, and the surface became snow-free at the beginning of July. In 2005 the winter accumulation was larger than the mean and the surface albedo stayed high until mid-August when the surface became snow-free. Although the duration of the ice melt varies, the ice albedo values are similar in both years and fluctuate around 0.3. Late-summer snowfalls at the end

Table 3. The contribution to melt of the components in the energy balance at Storbreen for the individual years $2002-06$ and the mean for the whole period

\begin{tabular}{|c|c|c|c|c|c|c|}
\hline Flux & 2002 & 2003 & 2004 & 2005 & 2006 & $2001-06$ \\
\hline Shortwave, $S_{\text {net }}\left(\mathrm{W} \mathrm{m}^{-2}\right)$ & 98 & 102 & 91 & 65 & 108 & 92 \\
\hline Sensible, $H_{\mathrm{S}}\left(\mathrm{W} \mathrm{m}^{-2}\right)$ & 21 & 20 & 15 & 20 & 23 & 20 \\
\hline Latent, $H_{\mathrm{L}}\left(\mathrm{W} \mathrm{m}^{-2}\right)$ & 11 & 9 & 4 & 11 & 11 & 9 \\
\hline Subsurface heat flux, $G\left(\mathrm{~W} \mathrm{~m}^{-2}\right)$ & -1 & -2 & -1 & -2 & -2 & -2 \\
\hline Radiation $\left(\mathrm{W} \mathrm{m}^{-2}\right)$ & 95 & 97 & 86 & 63 & 100 & 86 \\
\hline Turbulent $+G\left(\mathrm{~W} \mathrm{~m}^{-2}\right)$ & 30 & 27 & 18 & 29 & 33 & 27 \\
\hline Total, $Q\left(\mathrm{~W} \mathrm{~m}^{-2}\right)$ & 125 & 124 & 105 & 92 & 133 & 113 \\
\hline Radiation (\%) & 76 & 78 & 83 & 68 & 75 & 76 \\
\hline Turbulent (\%) & 24 & 22 & 17 & 32 & 25 & 24 \\
\hline
\end{tabular}




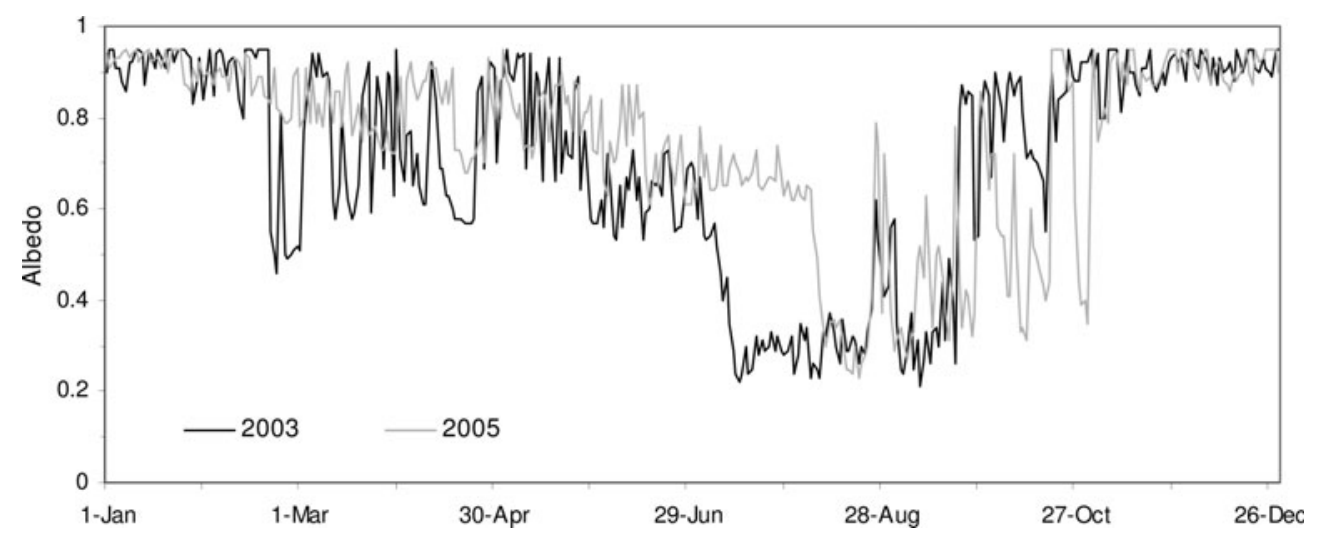

Fig. 8. Daily albedo for 2003 and 2005.

of August increased the albedo. Several melt episodes occurred during the autumn, and the surface albedo fluctuated greatly in both years until the end of October.

Ice albedos below 0.3 are found in all years, but the minimum values increase slightly during the observation period. In 2002 and 2003, ice albedos as low as 0.22-0.23 were found. In 2006, the lowest daily ice albedo was 0.26 . The mean summer albedo ranges from 0.44 in 2006 to 0.60 in 2005 (Table 2).

\section{Longwave radiation}

The largest absolute fluxes in the energy budget are $L_{\text {in }}$ and $L_{\text {out }}$, but they nearly cancel each other. The $L_{\text {in }}$ summer mean ranges between 302 and $313 \mathrm{~W} \mathrm{~m}^{-2}$, while the $L_{\text {out }}$ ranges between -314 and $-315 \mathrm{~W} \mathrm{~m}^{-2}$ (Table 2 ). $L_{\text {net }}$ is generally negative, but is positive several days each summer when the atmosphere is warm and humid.

\section{Turbulent fluxes}

The sensible heat flux $\left(H_{\mathrm{S}}\right)$ is positive most of the year, whereas the latent heat flux $\left(H_{\mathrm{L}}\right)$ is negative most of the time, but becomes positive in the summer months, indicating condensation instead of sublimation. The summer mean value of $H_{\mathrm{S}}$ varies between 17 and $24 \mathrm{~W} \mathrm{~m}^{-2}$ and is generally highest in the warmest years. $H_{\mathrm{L}}$ is much smaller than $H_{\mathrm{S}}$; the summer mean $H_{\mathrm{L}}$ ranges between 5 and $15 \mathrm{Wm}^{-2}$. Seasonal mean values of turbulent scales of wind speed, temperature and humidity, $u_{*}, \theta_{*}$ and $q_{*}$ (Table 2), reveal that $\theta_{*}(0.16-0.21)$ makes the largest contribution to the turbulent fluxes, $u_{*}(0.11-0.13)$ is smaller and is nearly constant for the 5 years and $q_{*}(0.02-0.05)$ has less influence on the fluxes than the other scales.

\section{Surface energy budget during melt}

The surface energy-balance calculations for the whole observation period 2001-06 show that the surface is at melt (defined as $Q>0$ and $T_{\mathrm{s}}=0^{\circ} \mathrm{C}$ ) for $33 \%$ of the time (using 1 hour values averaged from $30 \mathrm{~min}$ values). The total energy flux $(Q)$ contributing to melt averaged over the whole period is $113 \mathrm{~W} \mathrm{~m}^{-2}$ (Table 3). Of this, $S_{\text {net }}$ is the dominant contributor $\left(92 \mathrm{~W} \mathrm{~m}^{-2}\right)$, followed by $H_{\mathrm{S}}\left(20 \mathrm{~W} \mathrm{~m}^{-2}\right)$ and $H_{\mathrm{L}}$ $\left(9 \mathrm{~W} \mathrm{~m}^{-2}\right) . \quad L_{\text {net }}\left(-6 \mathrm{~W} \mathrm{~m}^{-2}\right)$ and $G\left(-2 \mathrm{~W} \mathrm{~m}^{-2}\right)$ contribute negatively to the budget. Thus, our results show that net radiation produces $76 \%$ of the melt energy, while the turbulent fluxes and the subsurface heat flux produce $24 \%$. The relative contribution of net radiation varies from $68 \%$ in 2005 to $83 \%$ in 2004 . The contribution of $H_{\mathrm{S}}$ and $H_{\mathrm{L}}$ to melt (Table 3 ) is similar to the seasonal mean averages (Table 2). The interannual variation in the SEB is mainly caused by variation in $S_{\text {out }}, H_{\mathrm{S}}$ and $H_{\mathrm{L}}$, while $S_{\text {in }}, G$ and $L_{\text {net }}$ are the components with the smallest interannual range (Tables 2 and 3 ).

\section{Melt season}

The duration of the melt season is illustrated in Figure 9, where all days with melt are plotted. Melt episodes occur in

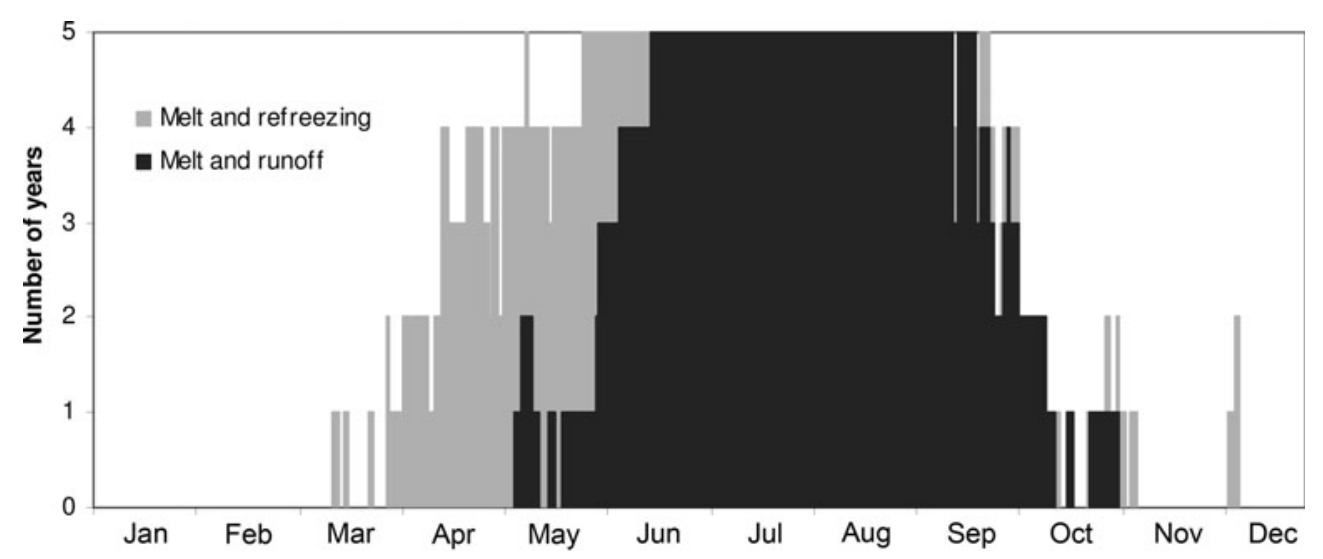

Fig. 9. Occurrence of melt episodes resulting in refreezing or runoff for the 5 year period of AWS observations (September 2001 to September 2006). For each calendar day the number of years with melting episodes on that day is plotted. The maximum number of years is five. 

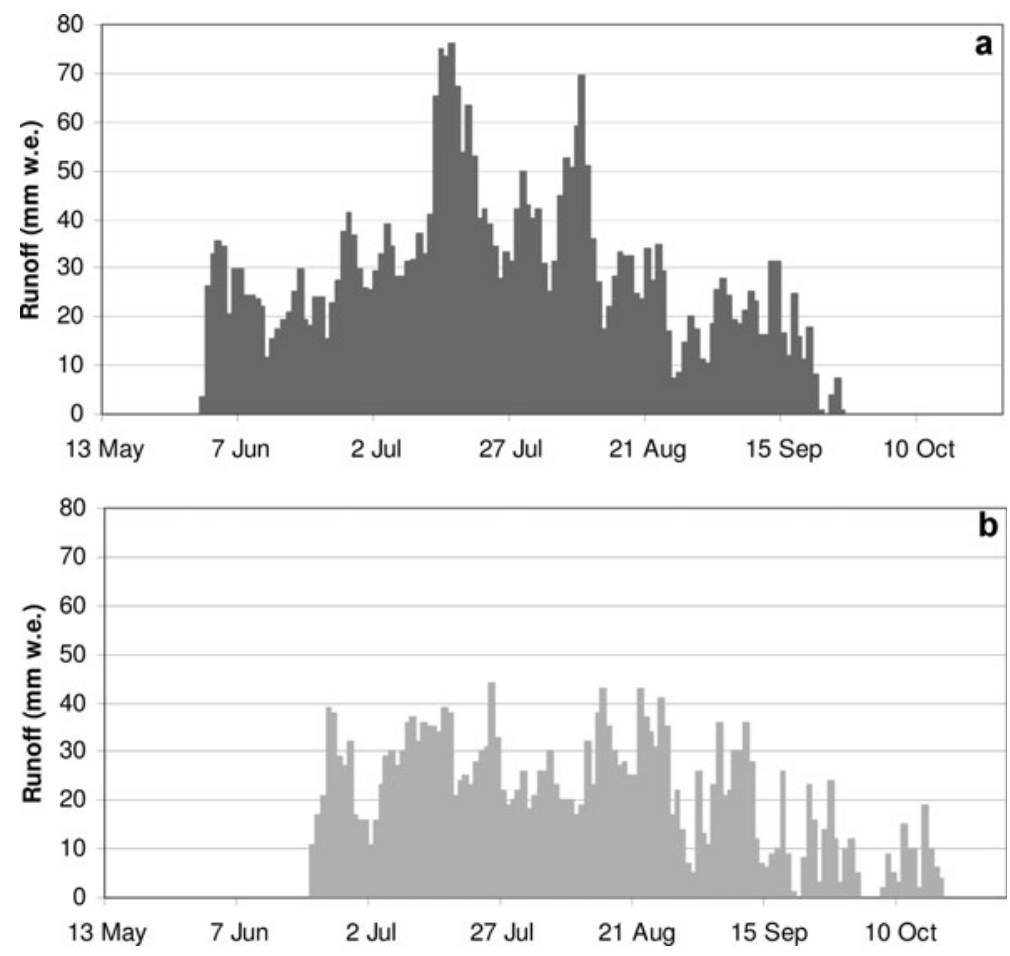

Fig. 10. Daily melt as runoff in 2003 (a) and 2005 (b). Melt which resulted in refreezing in the snowpack is not included.

all months of the year except January and February. Melt episodes in November through April resulted in refreezing in the snowpack. From May onwards, runoff may occur from the snowpack. The main melt season is June to August, when there is always melting during daytime. Melting continues in September, but the number of days with melting decreases towards October. The albedo data reveal that the surface becomes snow-free between the beginning of July and midAugust. The earliest exposure of glacier ice occurred in 2006 ( 6 July), and the latest in 2005 ( 11 August).

The highest melt rate is typically found from mid-July to mid-August, when the surface is snow-free, the albedo low and $S_{\text {in }}$ still rather high, which is illustrated for 2003 and 2005 in Figure 10. The melt season started earlier in 2003, with runoff from the glacier as early as late May. The melting peaked in mid-July with a daily melt of $76 \mathrm{~mm}$ w.e. The daily melt was lower in 2005, due to lower temperatures and the much shorter period of ice exposure at the surface, as also illustrated by the daily albedo values (Fig. 8). However, the melt season lasted until later in the year in 2005, mainly due to a warm October (Fig. 6).

\section{Accumulation and melt at the AWS site}

At the AWS site, the measured $b_{\text {acc }}$ ranged between 0.67 and $1.48 \mathrm{~m}$ w.e. (Table 4), with a mean of $0.95 \mathrm{~m}$ w.e. For four of the five years the $b_{\text {acc }}$ at the AWS was well below the mean $b_{\mathrm{w}}$ at this altitude, which is $1.40 \mathrm{~m}$ w.e. (for 16 years in the period 1971-2000). Ablation measurements at the stakes showed that the snowpack was removed each year and that a further 1.0 (in 2005) to 2.9 m w.e. (in 2002) of ice melted away from the glacier surface. The relative surface elevation and the stake readings for the total period of AWS observations are shown in Figure 11. The measured $b_{\mathrm{s}}$ from May to September (not including extra melt after the ablation measurements) varied between -2.47 (2005) and $-3.95 \mathrm{~m}$ w.e. (2002) with a mean of $-3.08 \mathrm{~m}$ w.e. Measured ablation from the stakes compares well with the runoff calculated from the SEB model (Fig. 3), and the interannual variations are well captured by the model considering the uncertainties in the measurements and the model. The total runoff for the whole period calculated with the SEB model (16.4 $\mathrm{m}$ w.e.) is the same as the calculated ablation from the total surface lowering from the stakes (Fig. 11) plus the summed measured $b_{\text {acc }}(11.7+4.7=16.4$ m w.e. $)$. The estimated accuracy in the total mass balance calculated from stakes and accumulation measurements is $\pm 0.20 \mathrm{~m}$ w.e. The total modelled melt and refreezing is 17.6 and $1.5 \mathrm{~m}$ w.e., respectively. The model results imply that $8 \%$ of the total superficially produced meltwater at the AWS location refreezes. This refreezing mainly takes place in April and May (Fig. 9).

Table 4. Measured winter accumulation, $b_{\mathrm{acc}}$, in May and summer ablation of snow and ice, $b_{s}$, from May to September. Note that the table does not include additional melting after the September measurements

\begin{tabular}{|c|c|c|c|c|c|}
\hline \multirow[t]{3}{*}{ Year } & \multicolumn{2}{|c|}{ Date of stake measurement } & \multirow{2}{*}{$\begin{array}{c}b_{\mathrm{acc}}=-b_{\mathrm{s}} \\
\quad(\text { snow })\end{array}$} & \multirow{2}{*}{$\begin{array}{c}b_{\mathrm{s}} \\
\text { (ice) }\end{array}$} & \multirow{2}{*}{$\begin{array}{c}b_{\mathrm{s}} \\
(\text { snow }+ \text { ice) }\end{array}$} \\
\hline & $b_{\text {acc }}$ & $b_{\mathrm{s}}$ & & & \\
\hline & & & mw.e. & mw.e. & mw.e. \\
\hline 2002 & 7 May & 20 September & 1.04 & -2.91 & -3.95 \\
\hline 2003 & 15 May & 28 September & 0.88 & -2.41 & -3.29 \\
\hline 2004 & 12 May & 14 September & 0.67 & -1.84 & -2.51 \\
\hline 2005 & 14 May & 30 September & 1.48 & -0.99 & -2.47 \\
\hline 2006 & 9 May & 8 September & 0.68 & -2.50 & -3.17 \\
\hline \multicolumn{3}{|c|}{ Cumulative } & 4.74 & -10.64 & -15.38 \\
\hline \multicolumn{3}{|l|}{ Mean } & 0.95 & -2.13 & -3.08 \\
\hline
\end{tabular}




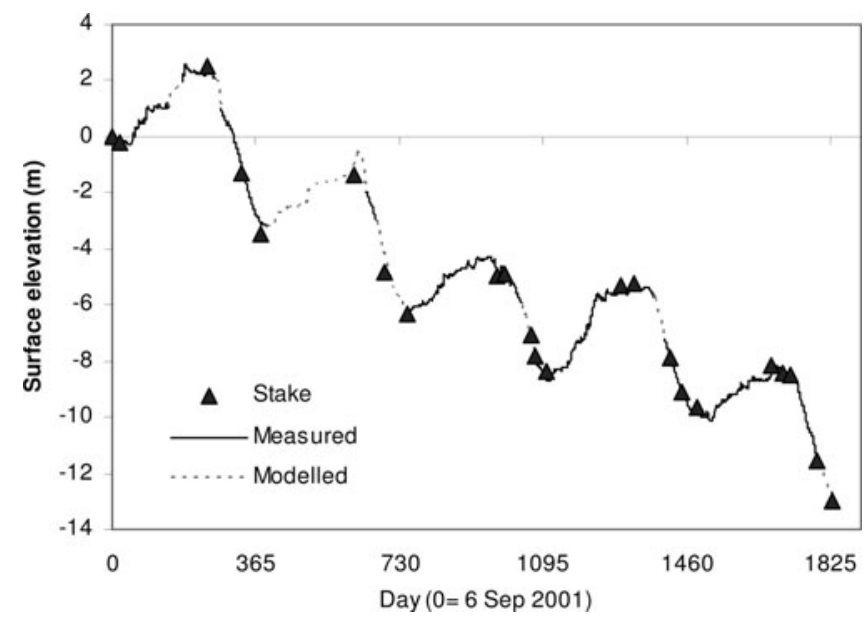

Fig. 11. Surface elevation measured from sonic-ranger data and stake readings. The gaps in the data are filled using precipitation data from the weather station Bråta (data provided by The Norwegian Meteorological Institute) in the accumulation season, and using the SEB modelled values converted to snow or ice during the melt season.

\section{Glacier-total mass balance}

The specific winter, summer and net balances measured at Storbreen in the period of the AWS observations, 2001-06, deviate markedly from the means of the reference period, 1971-2000, (Fig. 12). Four of the five years had a more negative summer balance than the mean of the reference period. The $b_{\mathrm{s}}$ measured in 2006, 2002 and 2003 are the largest, second largest and fourth largest negative balances ever measured at the glacier, coinciding with three of the warmest summers measured in Norway since measurements began in 1876 (Andreassen and others, 2005, 2007). The $b_{w}$ measured is lower than the mean of the reference period for four of the five years. The combination of more negative $b_{\mathrm{s}}$ and lower $b_{\mathrm{w}}$ than the average for the reference period led to pronounced deficits in four out of five years. The deficit in $2006,-2.1 \mathrm{~m}$ w.e., is the largest ever measured at the glacier (Andreassen and others, 2007; Kjøllmoen and others, 2007). Only in 2004/05 was the glacier nearly in balance, with a very small deficit. The mean net balance for the period 2001-06 is -1.2 mw.e., while the mean of the reference period, 1971-2000, is $-0.1 \mathrm{~m}$ w.e. Thus, the AWS observations cover a 5 year period with an unusually strong mass deficit on Storbreen.

\section{DISCUSSION}

\section{Sensitivity of the model to variations in $z_{0 \mathrm{v}}$}

Roughness length for momentum values recorded over melting glaciers has been reported to vary over three orders of magnitude, from 0.2 to $50 \mathrm{~mm}$ (Brock and others, 2006). Our two-step $z_{0 v}$ values of $0.13 \mathrm{~mm}$ when the surface is snow and $0.75 \mathrm{~mm}$ when the surface is ice, are within, but in the lower range of, the reported values from other glaciers. As described above, the median values were derived from the Midtdalsbreen AWS data due to the small sample of data points available for Storbreen, and this might introduce errors. As the data were similar in periods where they were available for both stations, however, there is good reason to believe that the chosen median values are representative of Storbreen.

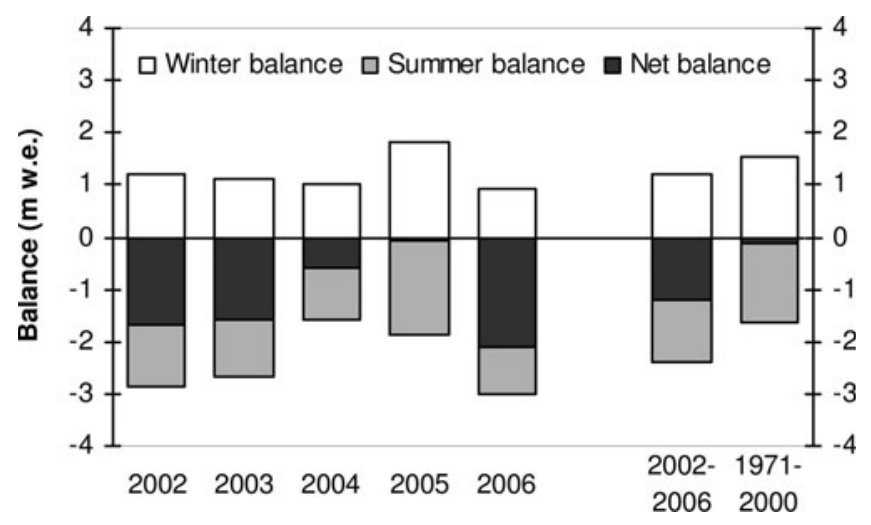

Fig. 12. The specific observed mass balance at Storbreen (glacier total) for the 5 years of AWS observations. The mean of this 5 year period and that of the reference period, 1971-2000, are also included.

The uncertainty in determination of the roughness length for momentum, $z_{0 v}$, has been identified as the largest uncertainty in the calculation of the turbulent fluxes (Braithwaite, 1995), although Munro (1989) noted that use of the parameterization of Andreas (1987) ensures that when $z_{\mathrm{OV}}$ increases, $z_{\mathrm{OT}}$ decreases, and this strongly dampens changes in the fluxes. However, Klok and others (2005) revealed that their model was more sensitive to omitting the correction for stability (change in specific mass balance of $-0.45 \mathrm{~m}$ w.e.) than to increasing or decreasing $z_{0 \mathrm{v}}$ by one order of magnitude ( -0.13 and +0.13 m w.e., respectively).

We tested the sensitivity of our model to our chosen twostep value of $z_{0 v}$ by carrying out two additional runs with a constant $z_{0 v}$ of 0.13 and $0.75 \mathrm{~mm}$. Comparing the two runs using constant $z_{0 v}$ with the reference run using the two-step value of $z_{0 v}$ shows that when using $0.75 \mathrm{~mm}$, the mean $H_{\mathrm{S}}+H_{\mathrm{L}}$ increases by $7 \%$ and the total runoff increases by $0.29 \mathrm{~m}$ w.e. for the whole period. When using $0.13 \mathrm{~mm}$, the mean $H_{\mathrm{S}}+H_{\mathrm{L}}$ decreases by $10 \%$ and the total runoff by $0.59 \mathrm{~m}$ w.e. (Fig. 13). Accordingly, the total change in runoff is smaller using $0.75 \mathrm{~mm}$ than $0.13 \mathrm{~mm}$. Since most of the melt occurs when the surface is ice, the change due to using $z_{0 v}$ for ice when the surface is snow does not affect the melt as much as when $z_{0 v}$ for snow is used in the ice melt period. The calculated change in mean runoff is only +0.06 and -0.12 m w.e. $\mathrm{a}^{-1}$, representing a $2 \%$ increase or $4 \%$ decrease in runoff, respectively. Thus, the change in runoff by varying $z_{\mathrm{Ov}}$ by more than half an order of magnitude is not substantial compared to the total modelled runoff for the whole period (16.4 $\mathrm{m}$ w.e.). Our results are therefore not as sensitive to the chosen value of $z_{0 v}$ as studies by Braithwaite (1995) and Brock and others (2000b), but are more comparable with the sensitivity results of Klok and others (2005).

Although some of the variation in the sensitivity of $z_{0 \mathrm{v}}$ between studies might be due to differences in climatic setting and variation in absolute and relative size of energy fluxes and total melt, differences in model set-up may also explain much of the variation in sensitivity. The model used by Klok and others (2005) is very similar to the model we use, while the work by Braithwaite (1995) and Brock and others (2000b) does not use the expressions by Andreas (1987) to calculate $z_{0 \mathrm{~T}}$ and $z_{0 \mathrm{q}}$. Furthermore, as the model we use solves the energy balance by varying $T_{\mathrm{s}}$, relatively small errors in measurements or model parameters can be 


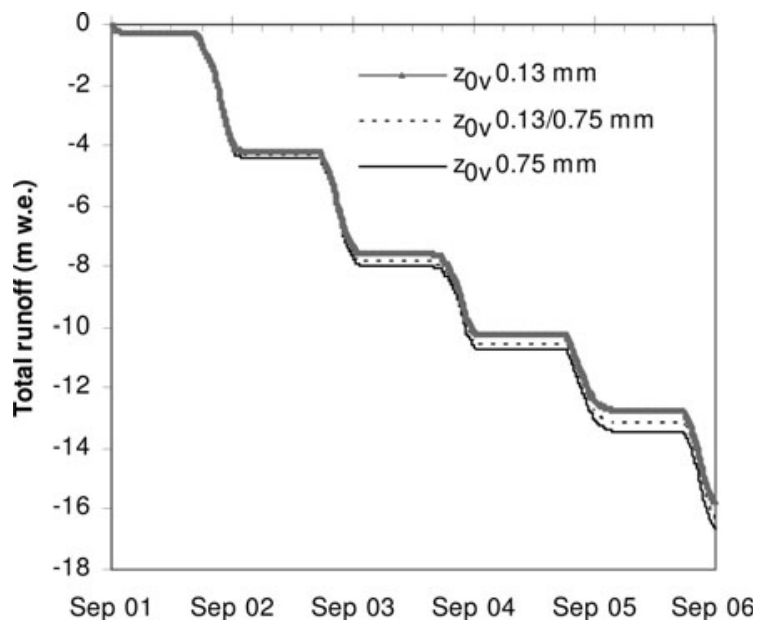

Fig. 13. Modelled cumulative runoff using three different parameterizations of $z_{0 v}$ : (1) constant $z_{0 v}=0.13 \mathrm{~mm}$ (as for a snow surface), (2) variable value of $z_{0 v}$, when surface is snow $z_{0 v}=0.13 \mathrm{~mm}$, or when surface is ice $z_{0 v}=0.75 \mathrm{~mm}$ (3) constant $z_{0 v}=0.75 \mathrm{~mm}$ (as for an ice surface).

compensated for by varying $T_{\mathrm{s}}$ and the turbulent fluxes. When the errors are larger the rmse will increase.

A study by Giesen and others (unpublished information), using the same model for Midtdalsbreen, reveals that uncertainties in the values of $z_{0 v}$, the stability functions and the ice density, as well as remaining errors in the radiation fluxes, all are the same order of magnitude. Thus to further improve the modelled SEB, all of these should be improved, not just $z_{0 v}$. Close correspondence between measured and modelled total and cumulative runoff as well as the calculated rmse of $T_{\mathrm{s}}$, however, lead us to conclude that both the surface energy-balance instrumentation and calculations are reliable and that the SEB model is robust and includes the main processes of melting at the AWS location.

\section{Sensitivity of the calculated energy balance and melt to variations in $T, \mathbf{R H}$ and WS}

To test the sensitivity of the calculated energy balance and ablation to changes in the input data, we prescribed perturbations of air temperature, $T,\left( \pm 1^{\circ} \mathrm{C}\right)$, wind speed, WS, $( \pm 10 \%)$ and relative humidity, $\mathrm{RH},( \pm 10 \%)$, and re-ran the model for the whole period, 2001-06. The sensitivity results only reveal the changes in turbulent fluxes, since the radiative fluxes and the snow depth are prescribed in the model from the measured data. Thus, the effect on the net radiative fluxes by varying $T, W S$ and $\mathrm{RH}$ is not included. Generally, the sensitivity is nearly the same for a decrease in the input data as for the same relative increase (Fig. 14). The sensitivity runs show that the runoff will increase by $0.33 \mathrm{~m}$ w.e. for a $1{ }^{\circ} \mathrm{C}$ increase in $T$, while it will decrease by $0.31 \mathrm{~m}$ w.e. for a $1{ }^{\circ} \mathrm{C}$ decrease (Fig. 14). The sensitivity to a $\pm 10 \%$ change in $\mathrm{RH}$ is almost as high as for a $1{ }^{\circ} \mathrm{C}$ change in $T,+0.28$ and $-0.29 \mathrm{~m}$ w.e. Sensitivity to increasing the WS by $10 \%$ was $+0.10 \mathrm{~m}$ w.e., a decrease gave $-0.10 \mathrm{~m}$ w.e. The results show that the model is three times more sensitive to a $1{ }^{\circ} \mathrm{C}$ change in $T$ than a $10 \%$ change in WS and that a rather high increase in $\mathrm{RH}$ and WS is needed to get the same effect as from a $1^{\circ} \mathrm{C}$ increase in temperature. Such an increase is beyond the observed interannual variation in $\mathrm{RH}$ and WS in the period of the measurements.

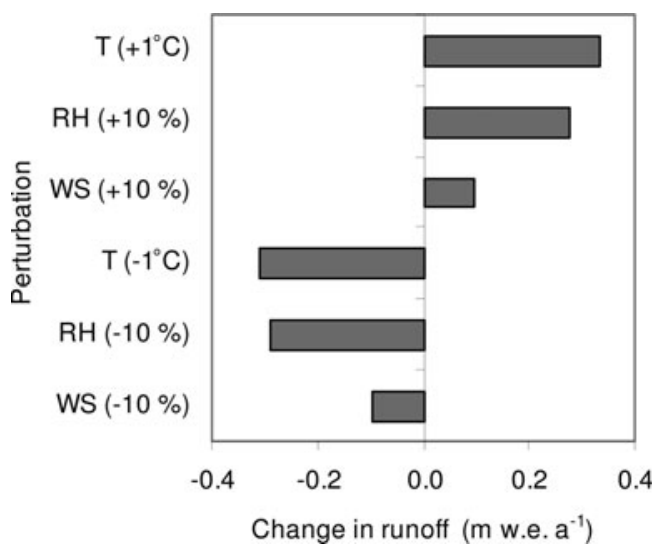

Fig. 14. Calculated change in total runoff for the period 2001-06 after applying perturbations to air temperature, $T\left( \pm 1^{\circ} \mathrm{C}\right)$, relative humidity, $R H( \pm 10 \%)$ and wind speed, WS $( \pm 10 \%)$.

\section{Importance of the individual components and interannual variability in SEB and melt}

Our results clearly reveal that net radiation is the most important energy source for melting at the AWS site at Storbreen, because it produces three-quarters of the total melt in the observation period. $S_{\text {net }}$ is thus by far the dominant energy flux, since $L_{\text {net }}$ has a smaller and negative contribution to the budget. $H_{\mathrm{S}}$ is twice as large as $H_{\mathrm{L}}$, and the turbulent fluxes together contribute one-quarter of the melt. The subsurface heat flux, $G$, plays a minor role in the total summer SEB. The relative importance of the individual components to the total melt varies between the years; the share of net radiation to the melt ranges between 68 and $83 \%$.

Comparison of the seasonal mean fluxes of the SEB reveals that $S_{\text {in, }} L_{\text {out }}$ and $G$ show little interannual variability (Table 2). While this result is as expected for $L_{\text {out }}$ and $G$, the result for $S_{\text {in }}$ is interesting and indicates that variations in cloud cover or others factors determining the atmospheric transmissivity are small in the main melt period and therefore have no significant influence on the interannual variations in melt at the AWS location.

Of all the components in the summer mean SEB, $S_{\text {out }}$ shows the largest range in magnitude $\left(33 \mathrm{~W} \mathrm{~m}^{-2}\right)$. The main difference in $S_{\text {net }}$ is caused by the variations in $S_{\text {out, }}$ implying that surface albedo has a strong influence on the magnitude of $S_{\text {net }}$ and thus on the total energy available for melt at Storbreen. The interannual ranges in $H_{\mathrm{S}}, H_{\mathrm{L}}$ and $L_{\text {in }}(7,10$ and $11 \mathrm{~W} \mathrm{~m}^{-2}$, respectively) are each of smaller magnitude than the range in $S_{\text {net, }}$ but summed they contribute considerably to the interannual variability. Simple correlation analysis of the set of five seasonal mean values shows that $89 \%$ of the variability in $b_{\mathrm{s}}$ is explained by the variation in $T\left(r^{2}=0.89\right)$. Although 5 years is a small set for this type of analysis, the result reflects, nevertheless, the importance of $T$ on many of the individual components of the SEB. $T$ directly influences $H_{\mathrm{S}}, H_{\mathrm{L}}$ and $L_{\text {in, }}$ and also affects $S_{\text {out }}$ through its influence on albedo. Air temperature will particularly control when the melt commences and how fast the winter snowpack is removed. Early exposure of glacier ice will amplify the melt due to the lower albedo of ice. Snow albedo is also influenced by air temperature and can be described empirically as a function of accumulated daily maximum temperatures since snowfall, as demonstrated by Brock and others 
(2000a). Furthermore, $T$ partly determines how long-lived summer snowfalls are, although this is not very important at the low altitude of the AWS. The seasonal mean $T$ and seasonal mean surface albedo are highly correlated $\left(r=-0.85, r^{2}=0.72\right)$. The amount of winter accumulation also has an impact on albedo $\left(r=0.72, r^{2}=0.52\right)$, as high $b_{w}$ will extend the period of snowmelt and reduce the period of ice melt, assuming other conditions are the same. The interannual variability in albedo, however, is more controlled by air temperature than $b_{\mathrm{w}}$ in the period of observations.

It is interesting to compare our results with the previously reported meteorological studies on Storbreen during the 1955 summer (Liestøl, 1967). The meteorological station in 1955 was located at $\sim 1600$ ma.s.I., at nearly the same altitude and about the same location as the present AWS considering the surface lowering of the glacier since 1955. Descriptions of the measurements and daily values are available for the period 6 July to 8 September. The period accounted for $\sim 80 \%$ of the ablation in 1955. In this period, radiation $\left(S_{\text {net }}+L_{\text {net }}\right)$ contributed $56 \%$, convection $\left(H_{\mathrm{S}}\right) 31 \%$ and condensation $\left(H_{\mathrm{L}}\right) \quad 13 \%$ of the melt. The weather observations are not published, but Liestøl (1967) reported a late start of the ablation, followed by a dry and warm summer. The $b_{\mathrm{w}}$ and $b_{\mathrm{s}}$ (only specific values for the whole glacier are reported) in 1955 were 1.57 and $-2.06 \mathrm{~m}$ w.e., respectively. These mass-balance values are most similar to the values of 2005 from our observation period. Using the same dates as in 1955, the 2005 data indicate the melt was made up of $61 \%$ radiation, $24 \%$ convection and $15 \%$ condensation. Our results cannot be compared directly with the results from 1955 due to differences in instrumentation, methods and calculations. Also, the snow and weather conditions were not identical. However, we can conclude that the previous results are comparable to ours with respect to the contribution of $S_{\text {net, }} H_{\mathrm{S}}$ and $H_{\mathrm{L}}$.

Previous studies on glaciers in Norway have revealed the contribution of net radiation generally decreased from the continental glaciers in the east $(70-80 \%)$ towards the maritime glaciers in the west (40-50\%), reflecting differences in synoptic climate from continental to more maritime conditions (Messel, 1985). Willis and others (2002) summarized values from other energy-balance studies, but their selection did not include any Norwegian glaciers. Their study suggests that in continental alpine areas the radiation and turbulent fluxes contribute on average $77 \%$ and $22 \%$, respectively, of the melt, while their selection from maritime alpine areas suggests the radiation and turbulent flux contributions were $49 \%$ and $50 \%$ on average, respectively. The mean values for Storbreen in the observation period 2001-06 are thus comparable to the values found on other continentally located glaciers.

\section{Melt at AWS location compared to glacier-total melt}

All the SEB results presented here apply to a single location in the ablation zone of the glacier and are not necessarily representative of the glacier total. The AWS is located at $\sim 1570$ m a.s.l., while the location of the equilibrium altitude of the glacier in balance is $\sim 1750$ ma.s.l. A study of the overall SEB for a 10 day period on Storbreen in 1955 revealed that the relative importance of net radiation, $H_{\mathrm{S}}$ and $H_{\mathrm{L}}$ was almost the same for the whole glacier $(54 \%$, $32 \%, 14 \%$ ) as for the location at the meteorological station on the tongue $(56 \%, 31 \%, 13 \%)$ (Liestøl, 1967).
Rasmussen and Andreassen (2005) studied the seasonal mass-balance profiles of ten glaciers in Norway including Storbreen. They found that the profiles are nearly linear for all glaciers and that the balance gradient varied little from year to year. Furthermore, their study showed that balance at a site near the middle of the altitude range of the glacier correlates best with glacier-total balance. The correlations, $r$, of $b_{\mathrm{n}}, b_{\mathrm{s}}$ and $b_{\mathrm{w}}$ at the altitude of the AWS site with the glacier-total $b_{\mathrm{n}}, b_{\mathrm{s}}$ and $b_{\mathrm{w}}$ are 0.94, 0.99 and 0.89, respectively (personal communication from A. Rasmussen, 2007). That is, there is a good correlation between the mass balance at the altitude of our AWS site and glacier-total balance. This does not necessarily imply that the SEB results from the AWS location are representative of the rest of the glacier, as the meteorological conditions will vary depending on surface topography and elevation, and extrapolation is not straightforward (Greuell and Smeets, 2001; Hock, 2005). However, as temperature $(T)$ and albedo explain most of the variation in $b_{\mathrm{s}}$ at the AWS site and as other factors (e.g. $\tau$ and WS), are of minor importance to the variability, the high ablation for the glacier total is mainly caused by high $T$ and by amplified melt caused by low mean albedo (due to high $T$ and low $b_{w}$ ).

The observed interannual variation in the relative and total magnitude of the surface energy balance fluxes points to the importance of making meteorological observations for several years to cover different weather and mass-balance conditions. As the AWS data cover a 5 year period with an unusually strong mass deficit on Storbreen, the results derived from the AWS in this period are not necessarily representative of previous years of mass-balance measurements. Observations for a few years with more balanced or positive glacier-total balances are desirable.

\section{CONCLUSIONS}

In this paper, we use a physically based energy-balance model to determine the surface energy balance from AWS data at Storbreen for the five mass-balance years from 2001/ 02 to 2005/06. The model calculates $L_{\text {out }}, H_{\mathrm{S}}, H_{\mathrm{L}}$ and $G$ as functions of the surface temperature, $T_{\mathrm{s}}$, while $S_{\text {in }}, S_{\text {out }}$ and $L_{\text {in }}$ fluxes are measured directly at the AWS. Good comparison between modelled and observed $T_{\mathrm{s}}$, as well as good agreement between modelled runoff and observed surface lowering measured from stakes and sonic-ranger data, indicate that all the important processes are included in the SEB model and that the calculations are robust. Model runs using perturbations of the input data show that the model is three times more sensitive to an increase or decrease in temperature by $1{ }^{\circ} \mathrm{C}$ than by increasing the wind speed by $10 \%$. The model is not as sensitive to the chosen value of the roughness length of momentum, $z_{0 \mathrm{v}}$, as previous studies.

Net radiation is the most important energy source for melting at the AWS site at Storbreen, producing threequarters of the total melt in the observation period. $S_{\text {net }}$ is the most dominant energy flux, while $L_{\text {net }}$ makes a negative contribution to the budget. The turbulent fluxes together contribute to one-quarter of the melt, the magnitude of $H_{\mathrm{S}}$ being twice the magnitude of $H_{\mathrm{L}}$. The subsurface heat flux, $G$, plays a minor role in the SEB of Storbreen, but calculations show that $8 \%$ of the meltwater refreezes. Refreezing mainly occurs in April and May.

$S_{\text {in }}$ shows little interannual variability, revealing that variations in cloud cover or other factors determining the 
atmospheric transmissivity have no significant influence on the interannual variations in melt at the AWS location. The main difference in $S_{\text {net }}$ is due to variations in $S_{\text {out, }}$ implying that surface albedo has a strong influence on the total energy available for melt at Storbreen. Variations in $T$ and albedo explain most of the interannual variation in $b_{\mathrm{s}}$ at the AWS site.

\section{ACKNOWLEDGEMENTS}

We thank B. Brock for a careful review which improved the paper and A. Rasmussen for valuable comments. We also thank IMAU personnel, particularly W. Boot, for erecting and maintaining the AWS at Storbreen. Furthermore, we thank Norwegian Water Resources and Energy Directorate (NVE) personnel for participating in the field for the massbalance observations. The work was sponsored by the Netherlands Foundation for Scientific Research (NWO) and NVE. G. Brånå from Statens Kartverk is thanked for providing orthophotos of Storbreen.

\section{REFERENCES}

Andreas, E.L. 1987. A theory for the scalar roughness and the scalar transfer coefficients over snow and sea ice. Bound.-Layer Meteorol., 38(1-2), 159-184.

Andreas, E.L. 2002. Parameterizing scalar transfer over snow and ice: a review. J. Hydromet., 3(4), 417-432.

Andreassen, L.M. 1999. Comparing traditional mass balance measurements with long-term volume change extracted from topographical maps: a case study of Storbreen glacier in Jotunheimen, Norway, for the period 1940-1997. Geogr. Ann., Ser. A, 81(4), 467-476.

Andreassen, L.M., H. Elvehøy, B. Kjøllmoen, R.V. Engeset and N. Haakensen. 2005. Glacier mass-balance and length variation in Norway. Ann. Glaciol., 42, 317-325.

Andreassen, L.M., H. Elvehøy and B. Kjøllmoen. 2007. Norske isbreer minket kraftig i 2007. Cicerone, 2.

Arnold, N.S., I.C. Willis, M.J. Sharp, K.S. Richards and W.J. Lawson. 1996. A distributed surface energy-balance model for a small valley glacier. I. Development and testing for Haut Glacier d'Arolla, Valais, Switzerland. J. Glaciol., 42(140), 77-89.

Braithwaite, R.J. 1995. Aerodynamic stability and turbulent sensible-heat flux over a melting ice surface, the Greenland ice sheet. J. Glaciol., 41(139), 562-571.

Brock, B.W., I.C. Willis and M.J. Sharp. 2000a. Measurement and parameterization of albedo variations at Haut Glacier d'Arolla, Switzerland. J. Glaciol., 46(155), 675-688.

Brock, B.W., I.C. Willis, M.J. Sharp and N.S. Arnold. $2000 \mathrm{~b}$. Modelling seasonal and spatial variations in the surface energy balance of Haut Glacier d'Arolla, Switzerland. Ann. Glaciol., 31, 53-62.

Brock, B.W., I.C. Willis and M.J. Sharp. 2006. Measurement and parameterization of aerodynamic roughness length variations at Haut Glacier d'Arolla, Switzerland. J. Glaciol., 52(177), 281-297.

Curry, J.A. and P.J. Webster. 1999. Thermodynamics of atmospheres and oceans. San Diego, CA, Academic Press.

Denby, B. and W. Greuell. 2000. The use of bulk and profile methods for determining surface heat fluxes in the presence of glacier winds. J. Glaciol., 46(154), 445-452.

Dyer, A.J. 1974. A review of flux-profile relationships. Bound.-Layer Meteorol., 7, 363-372.

Dyurgerov, M. 2000. Twentieth century climate change: evidence from small glaciers. Proc. Natl. Acad. Sci. USA (PNAS), 97(4), 1406-1411.
Greuell, W. and C. Genthon. 2004. Modelling land ice surface mass balance. In Bamber, J.L. and A.J. Payne, eds. Mass balance of the cryosphere: observations and modelling of contemporary and future changes. Cambridge, etc., Cambridge University Press.

Greuell, W. and P. Smeets. 2001. Variations with elevation in the surface energy balance on the Pasterze (Austria). J. Geophys. Res., 106(D23), 31,717-31,727.

Hock, R. 2005. Glacier melt: a review on processes and their modelling. Progr. Phys. Geogr., 29(3), 362-391.

Holtslag, A.A.M. and H.A.R. de Bruin. 1988. Applied modeling of the nighttime surface energy balance over land. J. Appl. Meteorol., 27(6), 689-704.

Kjøllmoen, B. and 6 others. 2007. Glaciological investigations in Norway 2006. Oslo, Norges Vassdrags og Energidirektorat. (NVE Rep. 1-2007.)

Klemsdal, T. 1970. A glacial-meteorological study of Gråsubreen, Jotunheimen. Nor. Polarinst. Årb., 1968, 58-74.

Klok, E.J. and J. Oerlemans. 2002. Model study of the spatial distribution of the energy and mass balance of Morteratschgletscher, Switzerland. J. Glaciol., 48(163), 505-518.

Klok, E.J., M. Nolan and M.R. van den Broeke. 2005. Analysis of meteorological data and the surface energy balance of McCall Glacier, Alaska, USA. J. Glaciol., 51(174), 451-461.

Liestøl, O. 1967. Storbreen glacier in Jotunheimen, Norway. Nor. Polarinst. Skr. 141.

Messel, S. 1971. Mass and heat balance of Omnsbreen: a climatically dead glacier in southern Norway. Nor. Polarinst. Skr. 156.

Messel, S. 1985. Energibalanse-undersokelser pa breer i Norge 1954-1981. In Roland, E. and N. Haakensen, eds. Glasiologiske undersøkelser i Norge 1982. Oslo, Norges Vassdrags-og Energiverk. Vassdragsdirektoratet, 45-59. (NVE Rapp. 01-1985.)

Mölg, T. and D.R. Hardy. 2004. Ablation and associated energy balance of a horizontal glacier surface on Kilimanjaro. J. Geophys. Res., 109(D16), D16104. (10.1029/2003JD004338.)

Munro, D.S. 1989. Surface roughness and bulk heat transfer on a glacier: comparison with eddy correlation. J. Glaciol., 35(121), 343-348.

Nesje, A., Ø. Lie and S.O. Dahl. 2000. Is the North Atlantic Oscillation reflected in Scandinavian glacier mass balance records? J. Quat. Sci., 15(6), 587-601.

Oerlemans, J. 2000. Analysis of a 3 year meteorological record from the ablation zone of Morteratschgletscher, Switzerland: energy and mass balance. J. Glaciol., 46(155), 571-579.

Oerlemans, J. 2001. Glaciers and climate change. Lisse, etc., A.A. Balkema.

Oerlemans, J. and B. Grisogono. 2002. Glacier winds and parameterisation of the related surface heat fluxes. Tellus $A$, 54(5), 440-452.

Ohmura, A. 2006. Changes in mountain glaciers and ice caps during the 20th century. Ann. Glaciol., 43, 361-368.

Østrem, G. and M. Brugman. 1991. Glacier mass-balance measurements. A manual for field and office work. Saskatoon, Sask., Environment Canada. National Hydrology Research Institute. (NHRI Science Report 4.)

Rasmussen, L.A. and L.M. Andreassen. 2005. Seasonal mass balance gradients in Norway. J. Glaciol., 51(175), 601-606.

Rasmussen, L.A., L.M. Andreassen and H. Conway. 2007. Reconstruction of mass balance of glaciers in southern Norway back to 1948. Ann. Glaciol., 46, 255-260.

Reijmer, C.H. and J. Oerlemans. 2002. Temporal and spatial variability of the surface energy balance in Dronning Maud Land, East Antarctica. J. Geophys. Res., 107(D24), 4759-4770.

Smeets, C.J.P.P. 2006. Assessing unaspirated temperature measurements using a thermocouple and a physically based model. In The mass budget of Arctic glaciers. Extended abstracts - Workshop and GLACIODYN Planning Meeting 2006. Utrecht, Institute for Marine and Atmospheric Research, 99-101. 
Van den Broeke, M.R. 1997. Momentum, heat and moisture budgets of the katabatic wind layer over a large mid-latitude glacier in summer. J. Appl. Meteorol., 36(6), 763-774.

Van den Broeke, M.R., D. van As, C. Reijmer and R. van de Wal. 2004. Assessing and improving the quality of unattended radiation observations in Antarctica. J. Atmos. Oceanic Technol., 21(9), 1417-1431.
Van den Broeke, M.R., C.H. Reijmer, D. van As, R.S.W. van de Wal and J. Oerlemans. 2005. Seasonal cycles of Antarctic surface energy balance from automatic weather stations. Ann. Glaciol., 41, 131-139.

Willis, I.C., N.S. Arnold and B.W. Brock. 2002. Effect of snowpack removal on energy balance, melt and runoff in a small supraglacial catchment. Hydrol. Process., 16(14), 2721-2749.

MS received 28 June 2007 and accepted in revised form 19 November 2007 